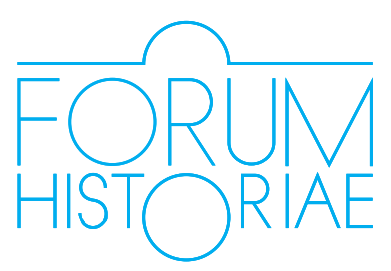

\title{
Rakouská ambasáda v Paříži v letech 1809 - 1812 v korespondenci Karla Schwarzenberga a Klemensa Metternicha
}

\author{
Milena Lenderová
}

\begin{abstract}
:
LENDEROVÁ, Milena: The Austrian Embassy in Paris from 1809-1812 in the Correspondence of Karl Schwarzenberg and Klemens Metternich.

The contribution deals with the period of time when Karl of Schwarzenberg was the Austrian Ambassador to Paris, that is the period of his Paris mission before the commencement of the campaign in Russia. It presents Schwarzenberg's personality as seen in his hitherto unstudied correspondence between him and Klemens von Metternich, plus some other sources of a personal nature, belonging to the same period and the same social ambience. The fundamental source was the 29 letters Schwarzenberg sent to Metternich from Paris. These map not only the social life in Paris, the world of diplomatic dealings, but also the private affairs of both figures.
\end{abstract}

Keywords: Metternich, Schwarzenberg, France, Austria, aristocracy

$\mathrm{V}$ mém př́íspěvku se budu věnovat období, které historiografii vztahující se k osobě Karla Philippa Schwarzenberga zatím zajímalo relativně málo: období, kdy byl maršálek rakouským velvyslancem v Paříži, resp. dobou jeho pařížské mise před zahájením tažení do Ruska. Schwarzenbergovu osobnost se pokusím přiblížit na základě zatím nezpracované korespondence mezi ním a Klemensem Metternichem, již budu konfrontovat s několika dalšími prameny osobní povahy, hlásícími se do stejné doby a stejného sociálního prostředí. Zmíním se rovněž o obou autorech dopisů, vrstevnících, kteří oba sloužili svému císaři, ale jejichž povahy i osudy byly rozdílné.

\section{Úvod}

Klemens Václav Lothar Nepomuk kníže Metternich (1773 - 1859) upoutal pozornost evropské historiografie záhy a těší se jí podnes. ${ }^{1}$ Karl Philipp Johann

1 Srov. např. SRBIK, Heinrich von. Metternich. Der Staatsmann und der Mensch, I.-III. München : Bruckmann, 1925 - 1945; BIBL, Viktor. Der Dämon Österreichs. Leipzig: Johannes Günther Verlag, 1936 atd. Z francouzských historiků se Metternichem zabývali např. MAZADE, Charles de. Un chancelier d'Ancien régime. Le règne diplomatique de M. de Metternich. Paris : E. Plon, Nourrit et Cie, 1889; BERTIER DE SAUVIGNY, Guillaume. Metternich et la France après le congrès de Vienne, I.-III. Paris : Hachette, 1968 - 1971; Metternich et son temps. 2. vyd. Paris : Fayard,1986; MISSOFFE, Michel. Metternich. 1773 - 1859. Paris : Librairie Arthème Fayard, 1959, 1986 atd. V české historiografii důkladná monografie chybí, za zmínku stojí např. HALADA, Jan (Jaroslav Šedivý). Metternich kontra Napoleon. Praha : Panorama, 1985, 1988, 1998, 2005 (první dvě vydání vydal pod svým jménem J. Halada, poslední dvě vyšla pod jménem J. Šedivého). Nejnovější sborník z konference BUDIL, Ivo - ŠEDIVÝ, Miroslav (ed.) Metternich a jeho doba. Sborník príspěvků z konference uskutečněné v Plzni ve dnech 23. a 24. dubna 2009. Plzeň : Fakulta filozofická Západočeské univerzity, 2009, je jistě vítaným počinem, ale historickou biografii nahradit nemůže. Z anglické historiografie připomeňme alespoň: ALGERNON, Cecil. Metternich. 1773 - 1859. A Study of his Period and Personality. London 1938; WARD, David. 1848: The Fall of Metternich and the Year of Revolution. London : H. Hamilton, 1970 (práce zaměřená výhradně na Metternicha za revoluce); McGUIGAN, Dorothy Gies. Metternich and the Duchess. New York : Doubleday, 1975. 
Nepomuk Joseph kníže Schwarzenberg (1771 - 1820), představitel druhého schwarzenberského majorátu, si svou první biografii zasloužil už roku 1823; ${ }^{2}$ další pak vyšly do konce „dlouhého 19. století“, 3 a to včetně první biografie české. ${ }^{4}$ Kvalitní moderní biografii má až dosud jen jednu; ${ }^{5} \mathrm{k}$ ní můžeme přičíst drobnější práce a studie vydané v češtině. ${ }^{6} \mathrm{Až}$ na českou oslavnou biografii Novákovu se všechny ostatní soustřed'ují na vojenskou kariéru maršálka, někdy na úkor ostatních složek jeho osobnosti.

Na rozdíl od Metternicha, jenž v myslích drtivé většiny Čechů zůstal spojen se zkostnatělým, eventuálně s prohnilým Rakouskem, symbolem reakce a národnostního útlaku, Schwarzenberg negativní emoce nebudil. Nepř́liš početná česká historická produkce ho hodnotila kladně jako čestného a statečného vojáka a velitele, ${ }^{7}$ což ale může být způsobeno skutečností, že se k němu nikdy nevyjádřilo ani nacionálně radikální, ani marxistické dějepisectví.

K charakteristice období, které mě bude zajímat, i k charakteristice obou jeho hlavních aktérů je možno vytěžit celou řadu editovaných pramenů; s některými z nich budu pracovat. ${ }^{8}$ Podobně je možné využít i pramenů archivních, včetně takových, které zůstávaly stranou pozornosti badatelů. ${ }^{9}$

Přibližme si alespoň v základních obrysech korespondenci, s kterou jsem pracovala. Nachází se ve Státním oblastním archivu Třeboň, ve fondu schwarzenberské sekundogenitury. Jedná se o fascikl 113 dopisů, které si mezi sebou vyměnili Klemens Metternich s Karlem Schwarzenbergem mezi léty 1809 až 1820; vznikly jako soukromý pandán oficiálních depeší a Karlovy korespondence adresované úřední cestou Metternichovi do Vídně. Poslední dva dopi-

2 PROKESCH-OSTEN, Anton. Denkwürdigkeiten aus dem Leben des Feldmarschals Fürsten Carl zu Schwarzenberg. Wien : Carl Schaumburg et Comp,1823, 1861.

3 HELFERT, Josef Alexander. Feldmarschall Fürst Carl Schwarzenberg und der russische Feldzug im Jahre 1812. Wien : Anton Shweiger, 1866; BERGER, Adolf. Feldmarschall Karl Philipp Fürst Schwarzenberg, Salzburg, 1882; KERCHNAWE, Hugo - VELTZÉ, Alois. Feldmarschall Karl Fürst zu Schwazenberg, der Führer der Verbündeten in den Befreiungskriegen. Wien und Leipzig : Wiedling, 1913.

4 NOVÁK, Jan Bedřich. Polní maršál Karel kníže ze Schwarzenberga. Historický portrét podle rodinné korespondence. Praha : Historický klub, 1913.

5 SCHWARZENBERG, Karl. Feldmarschall Fürst Schwarzenberg. Die Sieger von Leipzig. Wien - Munich : Herold, 1964.

6 HANESCH, Josef. Karel I. Filip, kníže Schwarzenberg. České Budějovice : Veduta, 2003. V souvislosti s bitvou u Lipska si maršálkova života všímá RAK, Jiří. Zapomenuté vítězství, zapomenutý maršál. Druhý život „bitvy národů“ u Lipska. In BEZECNÝ, Zdeněk - GAŽI, Martin - PUTNA, Martin C. (ed.) Schwarzenbergové $v$ české a středoevropské kulturní historii. České Budějovice : Národní památkový ústav, 2008, s. 403-414; CHALINE, Olivier. Karl Philipp zu Schwarzenberg, le vainqueur de Leipzig, octobre 1813. In CHALINE, Olivier - CERMAN, Ivo (ed.) Les Schwarzenberg. Une famille dans l'histoire de l'Europe XVI ${ }^{e}$ XXI siècles. Panazol : Lavauzelle, 2012, s. 81-95.

7 NOVÁK 1913, Polní maršál, s. 45-61; Novák se zde vymezuje proti některým kritickým výhradám německé vojenské historiografie, především na s. 48-49.

8 Srov. např. METTERNICH. Richard de. Mémoires, documents et écrits divers laissés par le prince de Metternich, chancelier de cour et d'État, 1-3, (editoval M. A. de Klinkowstroem), Paris : E. Plon et Cie, 1886 - 1908; NOVÁK, Johann Friedrich. Briefe des Feldmarschalls Fürsten Schwarzenberg an seine Frau. 1799 1816. Wien : Gerlach \& Wiedling, 1913; CLARY-ALDRINGEN, Charles. Trois mois à Paris lors du mariage de l'Empereur Napoléon Ir et de l'Archiduchesse Marie-Louise. Paris : Bon le Mitis et Cte de Pimodan, 1914, atd. 9 Státní oblastní archiv (SOA) Plzeň, Rodový archiv Windischgrätzů, inv. č. 1682, karton (k.) č. 442, Deník Eleonory Sofie Schwarzenberg (sestra Karla Filipa); SOA Třeboň, Rodový archiv Schwarzenbergů, primogenitura (dále RAS-prim.), fasc. 539, Fürstin Pauline, Tagesbuch; SOA Třeboň, Rodový archiv Černínů, Deníky Františky Knevenhüllerové aj. 
sy pocházejí z roku 1822, napsali si je Metternich a starší bratr Karla, Josef. ${ }^{10}$ Velká většina těchto listů náleží provenienčně do rodinného archivu Schwarzenbergů, nicméně část, která mě bude nejvíc zajímat, totiž období Schwarzenbergovy pařížské mise, se nachází v Rodinném archivu Metternichů a do fondu schwarzenberské sekundogenitury se dostala v opisech pořízených pravděpodobně metternichovským archivářem Hemerleinem. Korespondence, výhradně ve francouzštině, je chronologicky uspořádána a rozdělena do sedmi složek, každá z nich je uvozena jakýmsi podacím protokolem v podobě tabulek, které sestavil rovněž Hemerlein. K některým dopisům jsou připojeny rukopisné transkripce, dílo třeboňského archiváře Josefa Hanesche. ${ }^{11}$

Jak bylo řečeno, zajímat mě bude 29 Schwarzenbergových dopisů, posílaných z Paříže Metternichovi. První byl napsán 4. prosince 1809, poslední 23. května 1812. Z pochopitelných důvodů chybí vzájemná korespondence z období cesty arcivévodkyně Marie Louisy do Francie a z prvních měsíců jejího francouzského pobytu: Metternich byl od konce března do konce září 1810 v Paříži, se Schwarzenbergem, jak víme z jiných pramenů, ${ }^{12} \mathrm{v}$ osobním kontaktu.

Lze předpokládat, že dochovaný a svým způsobem znovuobjevený materiál má svůj vlastní př́íběh: Josef Hanesch, který se o osudy Karla Schwarzenberga po celý svůj život zajímal, uvažoval o souborném vydání této korespondence a nesporně také o důkladné Schwarzenbergově biografii. Ze záměru zůstaly jen dva tematické katalogy, ${ }^{13}$ kam se ale žádný z dopisů uložených v zkoumaném korpusu nenachází, a životopisné torzo maršálkovo, vydané z Haneschovy pozůstalosti v roce $2003 .^{14}$

Celý soubor Schwarzenbergových dopisů představuje materiál nevytěžený, bohatý, který by si zasloužil více pozornosti, než jsem mu mohla věnovat.

\section{Dva vrstevníci}

Vrstevníci Metternich a Schwarzenberg, navzdory svým rozdílným povahám patrně přátelé, žili dva různé životy. Co do rodového původu si nebyli zpočátku rovni: Schwarzenberg se jako kníže narodil, Metternichové byli knížaty až od roku 1813. Bezpečně víme, že se spolu setkali při korunovaci Františka II.;15 mohli se ale znát už dříve.

Karel Philipp Schwarzenberg přišel na svět 18. dubna 1771 jako druhorozený syn Jana Nepomuka Schwarzenberga a Marie Eleonory, rozené Oettingen-Wallerstein.

10 SOA Třeboň, Rodinný archiv Schwarzenbergové - Orlík (RAS - Orlík), inv. č. 779, II - 87/1-27, k. č. 128, II 87 (Correspondenz zwischen S. D. Fürsten Carl Schwarzenberg, Feldmarschall und Minister Fürsten Metternich).

11 Josef Hanesch (1912 - 1995), středoškolský profesor, archivář, od roku 1938 archivář zámeckého archivu v Orlíku, od roku 1959 archivářem Státního oblastního archivu v Třeboni. Autor řady publikací.

12 Např. CLARY - ALDRINGEN 1914, s. 32, 42, 283.

13 HANESCH, Josef (ed.) Napoleonovo tažení do Ruska 1812 - 1813. (Dokumenty o účasti rakouského pomocného sboru v korespondenci Karla ze Schwarzenbergu). Praha : Archivní správa Ministerstva vnitra ČSR, 1972; HANESCH, Josef (ed.) Osvobozenecká válka 1813 - 1815 v dokumentech rodinného archivu schwarzenberské sekundogenitury. Tematický katalog. Třeboň, 1986.

14 HANESCH, Josef. Karel I. Filip, kníže Schwarzenberg, polní maršál. České Budějovice : Veduta, 2003. 15 SOA Třeboň, RAS prim., fasc. 539, Fürstin Pauline, Tagesbuch, s. 111 a další. 
Historické kořeny rodu Schwarzenbergů, který ve zkoumané době patřil bezesporu mezi nejbohatší rody Rakouska, sahají do 12. století. Inkolát v Čechách získal roku 1654 Jan Adolf, jenž roku 1660 nabyl Třeboně a o rok později koupil Hlubokou. Majetek znamenající základ k mocenskému postavení plynule rozšiřovali další představitelé rodu. Ještě Jan Adolf byl roku 1670 povýšen do knížecího stavu podle zásady prvorozenectví: knížecí hodnost příslušela tedy jen nejstaršímu synovi, ostatní členové rodu zůstali „pouhými“ hrabaty. Rozšíření knížecího titulu na všechny členy rodu Schwarzenbergů napomohla tragická náhoda: roku 1732 během lovu u Brandýsa nad Labem Adama Františka ze Schwarzenbergu zastřelil nedopatřením císař Karel VI. Velkorysé císařovo gesto, dávající všem členům rodu titul knížete, mělo tento tragický přehmat kompenzovat. Pro nevládnoucí členy rodu se podle německé a francouzské módy začalo užívat titulu princ či princezna. Spolu s Lobkowiczy, Salmy, Dietrichsteiny, Auerspergy, Fürstenbergy a Thurn-Taxisy patřili Schwarzenbergové na vrchol rakouské šlechtické hierarchie a k oporám vídeňského dvora, do společnosti, jež sama sebe označovala jako „první společnost“, „haute volée“ či „crème de la crème“.

Klement Václav Nepomuk Lothar Metternich, hrabě, později kníže Metternich-Winnenburg-Ochsenhausen, vévoda z Portely, se narodil 15. května 1773 v Koblenci jako syn Franze Georga Karla Josepha Johanna Nepomuka Metternicha-Winneburg a Marie-Beatrix, rozené de Kanegeck. Pocházel ze staré a slavné porýnské rodiny, která byla, stejně jako Schwarzenbergové, vždy věrna císaři. Také Metternichové sloužili v císařských armádách; roku 1623 se stali majiteli západočeského zámku Kynžvart. Na rozdíl od Schwarzenbergů byli jako porýnská šlechta výrazněji ovlivněni francouzskou kulturou.

Jak Schwarzenberg, tak Metternich byli vychováni v duchu francouzského osvícenství a německého filantropismu; na Metternicha měl po určitou dobu vliv dokonce muž, který se stal později jakobínem. ${ }^{16}$

Jak bylo u druhorozených synů obvyklé, Karel Philipp Schwarzenberg zahájil svou kariéru v armádě, k níž nastoupil v roce 1787, tedy v šestnácti letech. Ještě neukončil své vzdělání, ale otec prozíravě rozhodl, že válka, kterou vedlo Rusko a Rakousko proti Turecku, bude pro syna nejen vynikající životní zkušeností, ale i př́ležitostí vyznamenat se. Nemýlil se, roku 1790 byl už Karel Philipp majorem, roku 1796 mu byla udělena hodnost generálmajora, od roku 1812 byl polním maršálem. Dvě jmenování mu přinesl rok 1805 - stal se místopředsedou dvorní válečné rady a tajným radou. Kvality vojáka neovlivnily jeho senzibilitu a smysl pro rodinu; „krvavé řemeslo“ mu pomohlo urazit cestu od osvícenství k romantismu, od libertina k př́ísnému moralistovi: „Záliby ze mne učinily libertina, láska mě změnila v př́sného moralistu," napsal 7. srpna 1801 své ženě. ${ }^{17}$ Vojenské úspěchy mu otevřely cestu k diplomatické kariéře. Roku 1808 se stal rakouským vyslancem v Petrohradě; město opustil, aby se účastnil bitvy u Wagramu.

16 METTERNICH 1866, 1, s. 6.

17 NOVÁK 1913, Polní maršál, s. 31. V edici dopisů je tato část vynechána. 
Metternich začal svůj dospělý život jako diplomat. A úspěšný - po několika evropských postech se ve svých třiatřiceti letech stal velvyslancem v zemi, která byla v dané době pro Rakousko nejdůležitější: na úspěchu jeho francouzské mise závisel mír v Evropě. 0 jeho jmenování měl údajně zájem sám Napoleon, který si na místo rakouského ambasadora přál někoho z Kaunitzova rodu. Žádný vhodný Kaunitz nebyl k dispozici, tak padl los na Metternicha, který byl od roku 1795 manželem Kaunitzovy vnučky Eleonory. Velvyslancem v Paříži byl jmenován 18. května 1806. On sám i tehdejší rakouský státní kancléř Johann Philipp Karl Stadion (1763 - 1824) považovali prešpurský mír, podepsaný po bitvě u Slavkova, za pouhé příměří určené k tomu, aby Rakousko mohlo připravit odvetu.

Sociálně inteligentní a šarmantní Metternich snadno pronikl do nejvyšší pařížské společnosti. Zhruba 59 \% tehdejší francouzské aristokracie vyšlo z prostředí armády ${ }^{18}$ a bohatství u nich často suplovalo vkus a dobré vychování. Metternich se nenechal zneklidnit směsicí revoluční přímočarosti a restaurované aristokratické rafinovanosti (na napoleonský dvůr se z emigrace vracela šlechta) a stal se vítaným návštěvníkem obnovených salonů, v nichž se především intrikovalo, flirtovalo a politizovalo. I v tom se lišil od Schwarzenberga, jehož takový způsob společenského vyžití nelákal. Ba ani Paříž ho neoslnila, nelíbily se mu špinavé ulice, drahota a chyběl mu pravidelný pohyb, jímž byl zvyklý čelit hrozící obezitě: lov či cvičení se zbraní. ${ }^{19}$ Starost mu působilo také stěhování do hotelu Montesson obklopeného velkou zahradou, který shledal pro svou misi vhodný. ${ }^{20}$

Díky kontaktům (ony milostné zde hrály důležitou roli) se Metternichovi podařilo v Paříži vybudovat rozsáhlou zpravodajskou sít’; přes Napoleonovu sestru Caroline, provdanou Murat, dával do oběhu falešné informace, které se pak dostávaly k francouzskému císaři (např. tvrzení, že během roku 1808 převládla ve Vídni mírová strana, ačkoli opak byl pravdou). Všechny Metternichovy raporty adresované do Vídně se nesly ve společném tónu: zabránit císaři v předčasném nepřátelství s Francií. Nepodařilo se: když na jaře 1808 vpadl Napoleon do Španělska, začalo Rakousko opět tajně zbrojit. Od června se šířily pověsti o brzké válce mezi Rakouskem a Francií. Metternich se snažil tyto informace popírat, navíc Napoleon o válku s Rakouskem nestál. Po bratislavském míru dostal vše, co mu Rakousko mohlo dát, a svržení habsburské dynastie neměl v plánu - navíc s ohledem na španělské záležitosti potřeboval mír. V téže době začal uvažovat o rozvodu - přál si potomka, pokud možno od manželky, jejímž prostřednictvím by se povznesl mezi evropské dynastie. Napoleonovým úvahám ucházet se o jednu z Alexandrových sester učinil car rázný konec.

V dubnu 1809 začala válka, kterou vyprovokovalo Rakousko. Bylo osamoceno -

18 TULARD, Jean. Cour impérial. In Dictionnaire Napoléon. Paris : Fayard, 1989, s. 545.

19 Schwarzenberg manželce, Paříž, 13. 12. 1809. In NOVÁK 1913, Briefe des Feldmarschalls, s. 179-180.

20 Schwarzenberg manželce, Paříž, 13. 12. 1809; Paříž 27. 1. 1810. In NOVÁK 1913, Briefe des

Feldmarschalls, s. 179-180, 182. 
Rusko bylo vázáno podmínkami tylžského míru, Velká Británie poskytla pouze morální a finanční podporu. Rakouské jednotky francouzským čelit nedokázaly - 13. května okupovala francouzská vojska Vídeň, Napoleon byl, stejně jako roku 1805, opět v Schönbrunnu. Metternich zůstal zpočátku v Paříži, kde se obával o svou bezpečnost, nebot' pařížská společnost ho, nikoli oprávněně, považovala za strůjce válečného konfliktu. Začátkem června se dostal do Vídně, dlouhou cestu urazil v doprovodu francouzských důstojníků, „ochranky“.

Začátkem července prohrálo Rakousko bitvu u Wagramu a 12 . července bylo uzavřeno příměří ve Znojmě. Napoleona se nepodařilo přimět k ústupkům; Metternich, který měl původně v jednáních nahradit rozhodně protifrancouzského Stadiona, byl odvolán, vyjednávání bylo svěřeno Ferdinandu Antonínu Bubnovi ${ }^{21}$ a Janu Josefu Liechtensteinovi, ${ }^{22}$ kteří zjednali podmínky vídeňského (schönbrunnského) míru, podepsaného 14. října 1809; Rakousko se jím stalo mocností druhého řádu.

Nastalo částečné uklidnění, Vídeň se na „korsického netvora“ dívala příznivěji, francouzští důstojníci byli přijímáni ve vídeňských aristokratických i měšt'anských salonech a učili se tančit valčík. Stadion, považovaný za hlavního viníka porážky Rakouska, byl nahrazen Metternichem, toho měl v Paříži nahradit Karel Schwarzenberg. 0 jeho jmenování rozhodla úmluva z 27. ř́jna 1809, uzavřená mezi Liechtensteinem a Jeanem-Baptistem Champagnym, Napoleonovým ministrem zahraničí. ${ }^{23}$ Metternich řídil rakouskou diplomacii až do událostí roku 1848; od 1821 byl dvorským a státním kancléřem rakouské monarchie.

Byl nesporně jedním z nejlepších a nejzkušenějších evropských politiků - vždyt' do celoevropské politiky zasahoval po čtyřicet let. Zažil všechny úspěchy, které muže jeho doby a postavení těšily: vyhrával v politice i v kartách, ${ }^{24}$ snadno dobýval ženy. Patřil k těm, kteří válku jako prostředek politiky neuznávali, jistě i proto, že byl spíš lvem salonů než stratégem. Sám se pro ni svobodně rozhodl jen jednou, až když Napoleonova sláva poklesla, v době neúspěšného pražského kongresu v létě 1813. Osudným se mu stal jeho konzervatismus; omylem nebylo Metternichovo poválečné rozhodnutí restaurovat Evropu podle modelu z roku 1790, ale setrvávat na něm ještě o 30 let později. Za zmínku stojí též jeho naprostá absence sociálního cítění (u odchovance francouzského osvícenství a německého filantropismu vzácná!): na rozdíl od Schwarzenbergovy nenajdeme v jeho písemné pozůstalosti sebemenší zmínku o válečném utrpení neprivilegovaných vrstev společnosti. ${ }^{25}$

Jak je vidět, Schwarzenberg byl zcela jiného založení. Třebaže i on se - díky pečlivé výchově, jíž se mu dostalo - hladce pohyboval ve společnosti: uměl tan-

21 Ferdinand Antonín Bubna z Litic (1768 - 1825), stratég, diplomat a válečník.

22 Jan Josef I. Liechtenstein, (1760 - 1836), syn Franze Josefa I. (1726 - 1781), politik, vojevůdce, měl významný podíl na přestavbě lednického zámku.

23 BERTIER DE SAUVIGNY 1986, s. 114-115.

24 SOA Třeboň, RAS Černínů, Deníky Františky Knevenhüllerové, 1810, nestr., zápis z 24. 2.1810.

25 NOVÁK 1913, Polní maršál, s. 19-22; BERTIER DE SAUVIGNY 1986, s. 18. 
čit, psát slohově vytříbené dopisy, mluvil plynně francouzsky. Ale na rozdíl od Metternicha, který tomuto jazyku dával přednost jak v záležitostech diplomatických, tak rodinných a milostných, Schwarzenberg používal od roku 1812 v soukromé korespondenci raději němčinu. Svým založením nebyl přímočarým vojákem, ale milujícím a věrným manželem (v lednu 1799 se ve Vídni oženil s hraběnkou Marií Annou z Hohenfeldu, ovdovělou Esterházy) a starostlivým otcem tří synů: Bedřicha (1799 - 1870), Karla (1802 - 1858) a Edmonda (1803 - 1873). Pokud se Metternich jeví jako kosmopolitní aristokrat (v roce 1824 napsal: „Odjakživa byla mou vlastí Evropa..." $\left.{ }^{26}\right)$, pak se Schwarzenberg netajil svým kladným vztahem k Čechám a nejlépe se cítil na jihočeském Orlíku. ${ }^{27}$ Císaři sloužil věrně jako voják i diplomat, diplomacii ale nepovažoval za svůj životní úděl: „Přinutili mě ke kariéře, která mi nebyla blízká, ale sloužil jsem jí dvacet let. Obětoval jsem jí své záliby, ale myslí si snad někdo, že s lehkým srdcem a chladnou myslí budu přihlížet, jak se kvưli mé oddanosti trůnu hroutí můj majetek a štěstí mých dětí?" ${ }^{\text {"28 }}$ Zdá se, že k diplomatickým kličkám měl ducha málo oportunního a pružného; Schwarzenbergovy pevné zásady a neměnné způsoby kontrastovaly s ještěrčí přizpůsobivostí jeho brilantního předchůdce. Do pařížského rušného společenského života, probíhajícího ve znamení obnovené slávy salonů, se kníže př́liš nehodil a také se mu zde pranic nelíbilo. „(U)jišt’uji tě, že už nemůžu, že v tom, co dělám, jsem jen zpola úspěšný a netěší mě vůbec nic. Skutečné práci se věnuje jen málo. Dvưr, reprezentace, velká večeře, malá večeře, společnost, bál, maškarní ples a všechny ty návštěvy [...] v podstatě, příteli, tu Paříž nenávidím. Z těch tří měsíců, co tu jsem, bylo sotva 24 hodin příjemných. Ale neobávej se ničeho, dokud budu mít pocit, že tu jsem užitečný, najdu odvahu zůstat tak dlouho, jak bude třeba, "29 svěřil bratru Josefovi 14. ledna 1810.

Metternicha jedna revoluce vynesla ke slávě, další ho smetla. Pro Schwarzenberga platí jen první část věty - proslavil se ve válkách proti Francii, ale po Napoleonově boku se účastnil ruského tažení. Pak získal další válečné vavříny, především v bitvě u Lipska, a zemřel po dlouhé nemoci 15. ř́íjna roku 1820 v Lipsku. Metternich přežil svého př́ítele o 39 let, zemřel 11. června 1859 ve Vídni.

Jaký byl jejich osobní vztah? Nesporně zcela korektní a rovnocenný, přes počáteční nerovnost šlechtických titulů. Psali si otevřeně, byli schopni přijmout od druhé strany přátelskou výtku. Schwarzenberg píše Metternichovi hned v prvním dopise: „Tvrdil jste, že věž u sv. Štěpána vypadá, že spadne. Ale osoby, které sem prijíždějí z Vídně, to popírají, že prý nic takového nebylo potvrzeno. Moc prosím, nepište mi príště nic, co není ověřeno, nemáte představu, jak snadné

26 BERTIER DE SAUVIGNY 1986, s. 19.

27 NOVÁK 1913, Briefe des Feldmarschalls, s. 35; k Schwarzenbergově vztahu k Orlíku srov. mj. CHALINE, Olivier. Orlik, le siège de la sécundogéniture. In CHALINE - CERMAN 2012, s. 353-364.

28 SOA Třeboň, RAS - Orlík, inv. č. 779, II - 87/1-27, k. č. 128, II 87; Ch. Schwarzenberg C. Metternichovi, Paříž, 1. 10. 1810.

29 SOA Třeboň, RAS- Orlík, inv. č. 706, I-5d/1-33, Karel I. bratru Josefovi - dopisy 1793 - 1815. Karel Josefovi, Pař́ž́, 14. ledna 1810. 
je zde ztratit důvěru a velmi nepř́íjemně se kompromitovat. " ${ }^{30}$ Styl dopisů, které maršálek Metternichovi adresoval, je ve srovnání se stylem depeší uvolněný, méně formální.

Třebaže v jejich soukromé korespondenci jednoznačně převažují informace širšího společenského dosahu, najdeme v ní také zprávy ze společenského a rodinného života obou pisatelů. Připomeňme alespoň Schwarzenbergův dopis z 20. července 1811, kde gratuluje Metternichovi k narození dcery: ${ }^{31}$ „Přijměte mé gratulace k rozšíření Vaší rodiny. Víte, tak trochu jsem Vás následoval: Vy jste chtěl syna, a máte dceru, u mě je to přesně naopak. Snad to bude tou dobou, kdy je vše vzhůru nohama. “" 0 vzájemné důvěře svědčí i výměna klepů týkajících se především Napoleonova dvora, stejně jako naděje, kterou Schwarzenberg vkládal v Metternicha ve věci svých neutěšených hmotných poměrů.

\section{Schwarzenbergova pochmurná pařížská mise}

„Na můj návrh svěřil císař František francouzskou ambasádu knížeti Karlu Schwarzenbergovi. Byla to ta nejlepší možnost a další vývoj událostí to jen potvrdí," napsal Metternich ve svých pamětech. ${ }^{33}$ Cílem novopečeného rakouského ministra zahraničních věcí bylo sblížení habsburské monarchie s Francií. V tom se shodoval s přáním Napoleona: potíže ve Španělsku narůstaly, námořní hegemonie Anglie trvala, ruský car se zdál být nevypočitatelný; přičtěme k tomu Napoleonovy osobní ambice pozdvihnout se matrimoniálně mezi evropské dynastie a neúspěšné „námluvy“ u ruské arcikněžny. Metternichův plán měl tedy naději na úspěch.

Úkolem Karla Schwarzenberga bylo naplnit jeho představu. Aby mu pomohl orientovat se v nástrahách pařížského života, nechal Metternich Schwarzenbergovi v Paříži svého osvědčeného spolupracovníka Pierra-Jeana Floreta, sekretáře rakouské ambasády, a vlastní manželku. Eleonora byla dáma vzdělaná, taktní a vyrovnaná, která vydala za deset osobních poradců.

Na konci listopadu 1809 už Metternich věděl, že prosakující zprávy o Napoleonově rozvodu jsou pravdivé. Údajně to byla zapuzená Josefina, která - někdy koncem roku 1809 - pozvala do Malmaisonu paní Metternichovou a před Evženem de Beauharnais prohlásila: „Mám plán, jehož úspěch mi umožní věřit, že obět, již jsem přinesla, nebyla zbytečná: císař se ožení s Vaší arcivévodkyní. Mluvila jsem s ním o tom včera, řekl mi, že se ještě nerozhodl, ale myslím, že tak nakonec učiní, pokud to bude přijato z Vaší strany. “34 A Schwarzenberg v prosinci 1809 napsal Metternichovi: „Brzy zřejmě nastane velká událost. I když se mi zdá málo pravděpodobné, že by mi učinili zatím nejasné návrhy týkající se arcivé-

30 SOA Třeboň, RAS - Orlík, k. č. 128, II 87; Ch. Schwarzenberg C. Metternichovi, Paříž, 4. 12. 1809.

31 Leontina, nar. 18. 7. 1811 - 6. 11. 1861, od r. 1835 manž. Moritz gr. Szándor von Slavnitza.

32 SOA Třeboň, RAS - Orlík, inv. č. 779, II - 87/1-27, k. č. 128, II 87; Ch. Schwarzenberg C. Metternichovi, Paříž, 20. 7. 1811. Poslední dítě, Edmond, se narodilo 18. 11. 1803; naznačované těhotenství tedy zřejmě skončilo potratem (Marie Anna potratila několikrát, jak dokládají prameny).

33 METTERNICH 1866, 1, s. 95.

34 MAZADE 1889, s. 76; též ALGERNON 1938, s. 61-62. 
vodkyně Luisy, přesto bych rád znal názor Jeho Veličenstva. Pokud papež potvrdí rozvod a dá Napoleonovi svolení se znovu oženit, proč nevyužít možnosti, která nám aspoň na chvíli zajistí klid; jinou cestu, jak se přiblížit Napoleonovi, nemáme. Pasivní postoj nám nepomůže, je třeba se vyzbrojit odvahou a využít všech prostředků, které stát má. ${ }^{\prime 35} \mathrm{~V}$ lednu 1810 sondoval Napoleon půdu na pařížském maškarním plese, když tančil s madame Metternich; ta se o své dojmy podělila se Schwarzenbergem. Kníže zprvu namítal, že Napoleonovy rakouské námluvy narazí na odpor církve, která se nepochybně postaví proti sňatku arcivévodkyně s rozvedeným mužem. Dostalo se mu odpovědi, že právě první císařủv manželský svazek nebyl v souladu se zásadami kanonického práva. Napoleonovo manželství s Josefinou pak anuloval pařížský biskupský soudní dvůr, nicméně papež, jehož Napoleon držel v zajetí v Savonně, se k souhlasu zlomit nenechal.

Napoleon rozehrál rakouskou kartu naplno. Schwarzenbergovi to 6. ledna 1810 vysvětlil Eugène Beauharnais: volba francouzského císaře padla na Marii Luisu, ale smlouvu je nutno podepsat během několika hodin, nebot' jakékoli otálení bude posuzováno jako odmítnutí a císař se poohlédne jinde. Schwarzenberg, uklidněný Napoleonovým rozvodem, údajně neskrýval radost, že uvidí rakouskou arcivévodkyni coby císařovnu Francouzů. ${ }^{36}$ Dne 7. února 1810 poslal Napoleon k Schwarzenbergovi Beauharnaise, aby předložil vyslanci formální žádost a získal od něj písemné vyjádření. Téhož večera podepsali Schwarzenberg se Champagnym svatební smlouvu.

Na vkus císaře Františka byl běh událostí překotný: především nechápal, jak mohl Schwarzenberg se Champagnym podepsat smlouvu ještě před formálním požádáním o arcivévodkyninu ruku. Proto se ve Vídni snažili vydávat kontrakt ze 7. února za pouhý příslib, skutečná svatební smlouva bude prý podepsána až po všech náležitých formalitách a ve Vídni, kam odjeli vyjednávat hrabě Narbonne-Lara ${ }^{37}$ a vévoda Talleyrand-Périgord. ${ }^{38}$ Nakonec císař smlouvu 16. února ratifikoval. ${ }^{39}$

Napoleon, vděčný Metternichovi i Schwarzenbergovi za zprostředkování sňatku, kterým se postavil po bok jedné z nejstarších evropských dynastií, nabídl oběma zrušení mediatizace jejích sňatků v říši, což, jak uvádí Metternich ve svých pamětech, museli oba diplomaté s ohledem na své postavení odmítnout. ${ }^{40}$

Vídeňská společnost nereagovala na plánovaný sňatek jednoznačně. Zdaleka nešlo o všeobecně panující spokojenost, jak předstírá Metternich ve svých pamětech: „Obyvatelstvo Rakouska prijalo návrh tohoto svazku s nadšením, nebot'

35 SOA Třeboň, RAS, inv. č. 770, II-87/1-29, k. č. 128, Schwarzenberg Metternichovi, 4. 12. 1809. Mýlí se tedy Novák, který tvrdí, že Schwarzenberg byl ve věci Napoleonova sňatku „postaven před hotovou událost“. NOVÁK 1913, Polní maršál, s. 61.

36 MAZADE 1889, s. 79.

37 Louis Marie Jacques Amalric, hrabě de Narbonne-Lara (1755 - 1813), voják a diplomat.

38 Charles Maurice de Talleyrand-Périgord (1754-1838), patrně nejznámější a nejúspěšnější státník a diplomat období Francouzské revoluce, napoleonských válek, restaurace Bourbonů a Vídeňského kongresu. Pro své zásluhy obdržel několik vysokých šlechtických titulů.

39 SCHWARZENBERG 1964, s. 126.

40 METTERNICH 1866, 1, s. 103. 
po dlouhých válkách a obětech přinese naději na klid a mír. "41 Už během přípravy Napoleonova sňatku ve Vídni se vytvářela opozice proti tandemu Metternich Schwarzenberg. Vídeňané je označovali za frankofily, Metternich byl dokonce podezírán, zda není Napoleonem placen. Část rakouských elit sňatek schvalovala, část byla proti. Rychle se vytvořil obraz obětující se nevinné princezny, která sňatkem s „netvorem“ zachrání svou vlast. ${ }^{42}$ Tato představa byla blízká i Schwarzenbergovi, jak dokazuje jeho dopis Metternichovi z 21. prosince 1809: „Nelekněte se, když ř́kám, že je třeba ji obětovat. Jakékoli odmítnutí zmaří naději získat několik let míru a klidu a hrozí, že nás zruinuje. Můžeme váhat mezi pádem celé monarchie a neštěstím jedné princezny? Obětovali jsme miliony mužů, pro princeznu musí být ctí zachránit svou vlast a podrobit se této volbě. Myslím, že na tom bychom měli stavět, zůstat této myšlence věrni a nezastavit se před žádnými překážkami, kráčet $k$ svému cíli. ${ }^{43}$ Podstatně stručněji vyjádřil svůj názor na tuto alianci kníže Karel Josef Ligne. ${ }^{44}$

Dne 7. března 1810 požádal Louis Alexandre Berthier ${ }^{45}$ Napoleonovým jménem o ruku Marie Luisy a předal jí císařovu podobiznu v diamantovém rámečku. 0 dva dny později se Marie Luisa slavnostně vzdala nároků na rakouský trůn. Na cestu do své nové vlasti se vydala 13. března, dva dny poté, kdy ve vídeňském chrámu sv. Štěpána požehnal jejímu svazku s francouzským císařem sám vídeňský arcibiskup. Napoleona při sňatku zastupoval maršál Berthier, nevěstu přivedl k oltáři na Napoleonovo výslovné přání arcivévoda Karel. Jako státní host jel do Paříže také Metternich. Ubíral se přes Norimberk a Mety, na cestě u Châlons-sur-Marne ${ }^{46}$ se setkal se Schwarzenbergem a jeho ženou Marií Annou, kteří jeli $\mathrm{v}$ ústrety nové císařovně. ${ }^{47} \mathrm{~V}$ Pařiži zůstal Metternich do konce září, účastnil se všech slavností, které se zde v souvislosti s Napoleonovým sňatkem odehrály.

Rakouský vyslanec nemohl zůstat stranou. V pořádání slavností měl už jistou praxi: poprvé se Pařížanům představil 9. února 1810, kdy se jeho inaugurační slavnosti $v$ budově rakouské ambasády účastnilo kolem osmi set hostů. Toto pařížské entrée ho přišlo na 83982 franků a zřejmě v jeho průběhu si kníže uvědomil, že prostory paláce užívaného jako vyslanectví pro podobně velkorysé akce nedostačují. Další večírky - mezi 21. únorem a 21. březnem 1810 - byly

41 Dle Tamtéž, s. 99.

42 Srov. např. SOA Třeboň, Rodový archiv Černínů, Deníky Františky Knevenhüllerové, 1810, zápis z 26. 2. 1810, nestr.

43 SOA Třeboň, RAS - Orlík, inv. č. 779, II - 87/1-27, k. č. 128, II 87; Ch. Schwarzenberg C. Metternichovi, Paříž, 21. 12. 1809.

44 Charles-Joseph Lamoral, $7^{\text {e }}$ princ de Ligne (1735 - 1814), maršál, diplomat, literát, přezdívaný „největší z Wallonů“. Chystanou svatbu Napoleona s Marií Luisou komentoval údajně těmito slovy: „Je lepší, když jde do prdele jedna arcivévodkyně než celá monarchie."Cit. dle HALADA 1985, s. 109. Ve svých memoárech však kníže tuto myšlenku nijak nerozvádí, srov. LIGNE, Prince de. Mémoires, lettres, pensées. Paris : Editions François Bourin, 1989.

45 Louis Alexandre Berthier (1753 - 1815), napoleonský velitel, dosáhnuvší hodnosti Maršál Francie, suverénní kníže z Neuchâtelu, kníže z Wagramu a vévoda z Valanginu.

46 Město se nachází v departementu Marne, 167 km na východ od Paříže.

47 BERTIER DE SAUVIGNY 1986, s. 123-124. 
už skrovnější; vydání úhrnem nepřesáhlo 78700 franků. ${ }^{48}$ Skutečnost, že rakouské finance byly v bídném stavu (schylovalo se k bankrotu), nehrála - pokud se týče státní pokladny - roli: Karel ze Schwarzenbergu hradil své působení v Paříži a nákladnou reprezentaci z vlastních zdrojů, navzdory císařovu slibu, že se rakouský dvůr bude na financování provozu legace podílet. ${ }^{49}$

Chystaný bál na oslavu Napoleonova sňatku měl předstihnout všechna očekávání, především - a v tom byla snaha Schwarzenberga a Napoleona shodná přesvědčit obyvatelstvo Francie jak o přednostech mladé císařovny (Josefína byla příliš oblíbená na to, aby Francouzi přijali Marii Luisu s otevřenou náručí či alespoň bez výhrad), tak o výhodách této aliance. Skutečnost, že Rakušané se ve Francii netěšili sympatiím, není jistě třeba připomínat. Ples, jenž se konal 1. července $\mathrm{v}$ budově pařížského rakouského velvyslanectví v zahradě paláce Montesson, očekávání nesplnil - skončil tragicky. Při rozsáhlém požáru, k němuž došlo v průběhu bálu, uhořela velvyslancova švagrová Pauline Schwarzenberg. ${ }^{50}$ Pro ambasadora, který utrpěl velké materiální škody, byla smrt Pauliny traumatem, z něhož se nikdy zcela nevzpamatoval. ${ }^{51}$ Ani Metternichovy ambice nebyly naplněny: Napoleon zrušil dodatek schönbrunnské smlouvy, omezující početní stav rakouské armády na max. 150 tisíc mužů. Jinak nic.

K št’astným událostem napoleonského dvora, které se odehrály v době Schwarzenbergovy mise, patřilo narození Napoleonova syna. Podle Schwarzenberga bylo narození římského krále novým dokladem Napoleonova štěstí: francouzský císař byl podle něj na vrcholu svých sil a měl za to, že se mu splní vše, oč bude usilovat. ${ }^{52}$ Úspěch očekával i od připravované války s Ruskem.

Část Schwarzenbergovy pařížské mise se totiž odehrála ve znamení příprav Francie na tento klíčový konflikt. Schwarzenberg byl vnímavým pozorovatelem, byl si vědom toho, že ekonomické problémy Francie vedou k vnitřním nepokojům, které jsou tvrdě potlačovány. Že Napoleon opět používá staré taktiky: vyvolá novou válku a vojenskými úspěchy odvrátí pozornost lidu od hospodářských těžkostí. Je to zkušenost dostatečně prověřená, ostatně francouzský národ je podle Schwarzenberga stvořen k tomu, aby byl veden do dramatických událostí. ${ }^{53}$ Vyhlídky na válečný konflikt ho neplnily nadšením, byl si ale vědom toho, že se mu jeho země nedokáže vyhnout a že bude nezbytné respektovat Napoleonovo přání, aby Rakousko zaujalo místo po boku Francie: „Rusko hrozí a této bouře je třeba se bát. [?] Prosím, abyste mi co nejdříve sdělil instrukce, na základě kterých budu jednat. Nedá se pochybovat o tom, že běh událostí přinese brzy krizi, při níž nebude možné zaujmout pasivní postoj, je třeba myslet na to, že

48 SOA Třeboň, RAS - Orlík, Účty za plesové výdaje, sign. II-41-c/2. Srov. též Karel ze Schwarzenbergu manželce, Pařŕž, 14. 2. 1810. NOVÁK 1913, Briefe des Feldmarschalls, s. 184.

49 SOA Třeboň, RAS - Orlík, Hmotná situace rak. vyslanectví, 1810 - 1824, inv. č. 752, II-41 e, 1-3, k. č. 122.

50 Srov. LENDEROVÁ, Milena. Tragický bál. Život a smrt Pavlíny ze Schwarzenbergu. Praha : Paseka, 2004.

51 Schwarzenberg Feldeggovi, schwarzenberskému hofmistrovi, Paříž, 3. 7. 1810; dle SCHWARZENBERG 1964,s. 135-136.

52 SOA Třeboň, RAS - Orlík, inv. č. 779, II - 87/1-27, k. č. 128, II 87; Ch. Schwarzenberg C. Metternichovi, Paříž, 20. 3. 1811.

53 SOA Třeboň, RAS - Orlík, inv. č. 779, II - 87/1-27, k. č. 128, II 87; Ch. Schwarzenberg C. Metternichovi, Paříž, 3. 4. 1811. 
naším zájmem je, pokud možno, vycouvat. Pak ale neunikneme tomu, že naše kraje budou zaplaveny cizími vojáky. Srdce mi při tomto pomyšlení krvácí, zase se dostaneme do boje za cizí zájmy. Ale je třeba, aby stát odolal, vše ostatní je vedlejší, kromě cti vojáka. Jiný je zájem civilisty, jiný zájem státníka - na to je třeba myslet." ${ }^{44}$

Dne 18. prosince 1811 píše Schwarzenberg Metternichovi o svém rozhovoru s Napoleonem, k němuž došlo dva dny předtím. Císař v něm nastínil podmínky vojenského spojenectví s Rakouskem. Současně informoval Schwarzenberga o vojenské připravenosti Francie. Od Rakouska žádal armádu o síle 40 až 50 tisíc vojáků, která by operovala pod velením rakouského generála na pravém křídle francouzské armády. Vyjádřil přání, že by jí měl velet Schwarzenberg, a nastínil možné územní zisky Rakouska. Válku hodlal začít v polovině dubna $1812 .{ }^{55}$

Tentokrát byla vyjednávání pro Rakousko úspěšná: za slib pomocného sboru o 30 tisíc mužích mu Napoleon zaručil celistvost a slíbil některé územní zisky. Starostí jak Metternicha, tak Schwarzenberga bylo, aby Rakousku nevyšla válka draho a aby nedošlo k výraznému oslabení Ruska. Metternich vzkázal do Petrohradu, že se uzavření smlouvy nemohl vyhnout, ale že navrhuje, aby se obě vlády nadále informovaly o svých politických úmyslech. Současně slíbil Rusům, že rakouské sbory budou operovat jen na území Bukoviny.

Spojenecká smlouva mezi Rakouskem a Francií byla podepsána 14. března 1812 a způsobila další velké rozhořčení protimetternichovské opozice jak ve Vídni (protifrancouzské postoje dávali najevo především arcivévoda Karel, prezident dvorské komory Wallis, císařovna Marie Ludovika), tak v Praze (Stadion, František a Kašpar Šternberkové, baron Heinrich Stein).

Připomeňme ještě, že celá Schwarzenbergova pařížská mise byla kalena maršálkovými vážnými finančními problémy, které se kvůli výše zmíněnému požáru ještě prohloubily. Ve zkoumané korespondenci není v podstatě jediný dopis, kde by ambasador nežádal svého „cher ami“ Metternicha o intervenci u císaře, od něhož očekával jak obvyklou materiální podporu, jež velvyslanci po právu náležela, tak sanaci škod, k nimž došlo během tragického bálu: „Dovolte, drahý příteli, abych Vám řekl ještě dvě slova o svém postavení, které je skutečně špatné. Jsem na pokraji zruinování, pokud císař nesplní své sliby, že nepřipustí, abych se dostal do finančních potíží. Sám jistě víte, jak nákladný byl pobyt na pařižské ambasádě, daleko nákladnější, než tomu bylo kdysi. I Vy dobře víte, že ani Vašim financím neprospěl. Pokud mi císař nepomůže, prostě končím."56 Metternich se skutečně snažil něco v této záležitosti udělat, jak vyplývá ze Schwarzenbergova dopisu z 22. listopadu 1810: „To, co jste mi řekl o řešení mých finančních potíží, je pro mě dokladem Vašeho př́telství. Pochopil jsem, že dvưr na sebe vezme mé

54 SOA Třeboň, RAS- Orlík, inv. č. 779, II - 87/1-27, k. č. 128, II 87; Ch. Schwarzenberg C. Metternichovi, Paříž, 11. 12. 1810.

55 SOA Třeboň, RAS - Orlík, inv. č. 779, II - 87/1-27, k. č. 128, II 87; Ch. Schwarzenberg C. Metternichovi, Pař́žz, 18. 12. 1811. Depeši podobného znění, kterou poslal oficiální cestou Schwarzenberg Metternichovi o den dříve, editoval HANESCH 1972, s. 3-4. Srov. též ALGERNON 1938, s. 82.

56 SOA Třeboň, RAS - Orlík, inv. č. 779, II - 87/1-27, k. č. 128, II 87; Ch. Schwarzenberg C. Metternichovi, Paříž, 1. 10.1810. 
dluhy, což přijímám s vděkem a úlevou. "57

Když se Karel Philipp vrátil po ruském tažení zpět do Paříže jako velvyslanec, upozornil Napoleona, že císař František je stále nakloněn všeobecnému míru. Napoleon ale jakákoli mírová jednání odmítl, a tak se Karel Philipp vrátil zpět do Vídně, kde byl jmenován do čela armády. To byl faktický konec Schwarzenbergovy pařížské diplomatické mise, třebaže do Paříže se ještě podívá, mimo jiné jako velitel vítězných spojeneckých vojsk.

57 SOA Třeboň, RAS - Orlík, inv. č. 779, II - 87/1-27, k. č. 128, II 87; Ch. Schwarzenberg C. Metternichovi, Paříž, 22.11. 1810.

\section{Cituj:}

LENDEROVÁ, Milena. Rakouská ambasáda v Paříži v letech 1809 - 1812 v korespondenci Karla Schwarzenberga a Klemensa Metternicha. In Forum Historiae, 2018, roč. 12, č. 2, s. 30-42. ISSN $1337-$ 6861.

Milena Lenderová

Ústav historických věd

Fakulty filozofické Univerzity Pardubice

Studentská 84

53210 Pardubice

Milena.Lenderova@upce.cz 